\title{
BIO-ECONOMIC LOSS ASSESSMENT FOR GILTHEAD SEABREAM, IN BARDAWILL LAGOON, EGYPT
}

\section{Salem}

Faculty of Aquaculture and Marine Fisheries, Arish University

Received: 10/6/2018 Accepted: 15/1/2019

\section{SUMMARY}

Three fish landing centers were selected; west, middle and east of Bardawill lagoon to assess the losses of the biomass and value of the landings of juvenile Gilthead seabream (Sparus aurata) fish as one of the most important species in the fisheries of the trammel units. The study used landings of ten fishing vessels per month. Eight fishing trips were carried out each month from the end of April to the end of November 2017. The observed total length of 940 Gilthead bream, ranged from 15.2 to $29.8 \mathrm{~cm}$ and the weight from 47 to $385 \mathrm{~g}$. The

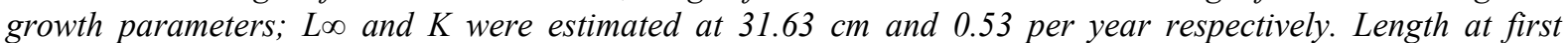
maturity $\left(L_{50}\right)$ and length at first capture $\left(L c_{50}\right)$ equals 22.5 and $18 \mathrm{~cm}$, respectively. Maximum biomass deficit was found in August. The study showed that there is a significant loss in the biomass and the corresponding income. The bio-economic model showed that if the juveniles of bream are allowed to grow up to length at first maturity $\left(\mathrm{Lm}_{50}\right)$, the additional biomass will be about 295.2 tons per year; the corresponding annual economic gain is estimated at LE 25.22 million for each fishing season. In order to protect bream stock and to enable it to share at least for one time in reproduction, the current fishing nets should be developed to reduce the Juvenile exploitation.

\section{Keywords: Gilthead bream, Sparus aurata, Juvenile landings, Bio-economic losses, Trammel units, Bardawill lagoon}

\section{INTRODUCTION}

Despite the availability of biological studies on fish species in Bardawill lagoon, juveniles fish proportion of economic importance was not measured in most of the studies conducted, nor did it address the destructive fishing behavior of various gears. The Gilthead bream fish is one of the most important species in Bardawill lagoon fishery. As a result of the increasing demand for this fish, it has been observed in recent years that most catches less than size at first maturity resulting in heavy fishing pressure on juveniles and immature of these resources in the lagoon (Salem, 2011). There are two types of fishing units (boat) allowed in Bardawill lagoon; trammel units and Veranda units. The trammel units are the main vessels to catch gilthead bream. The main problem in the trammel units that using of more than one gear such as passive trammel net, passive or active gillnets and hand line in the same fishing day. It is difficult to sort bream fish according to each type of gear. Non-target catches in the form of juveniles limits the future return and subsequent employment of fisheries. Most studies in the last years showed that, the stock of bream declined in Bardawill lagoon (Mehanna et al., 2011 and Salem and El-Aiatt, 2013). Overexploitation occurs when fish catch less than the optimum size of harvest (Diamond et al., 1999). Bio-economic analysis provides a more moderate screening of fisheries exploitation. Biological analysis can examine changes in growth, cohort sizes, reproduction and landings as it is the basis used to calculate current and expected future economic returns. Economic analysis can be used to predict the likely changes in returns. This can be useful in making the right decision especially for countries facing declining fisheries. The intensive exploitation of fish communities is a main reason of substantial decrease in the abundance of target species changing the species composition (Greenstreet \& Hall 1996). Bream fish undertake only limited migration from the lagoon to Mediterranean. Most fishers believe that using larger meshes would not be economical; it may be difficult to convince fishers that these small fish will return to them again in the form of higher economic returns unless it is demonstrated to them by numbers. Thus, the present paper aims to quantify the Bream juvenile landings of trammel fishing units in Bardawill lagoon and its economic evaluation.

\section{MATERIALS AND METHODS}

This work was carried out in Bardawill lagoon during 2017. Three landing sites were selected for the study (Figure 1). 


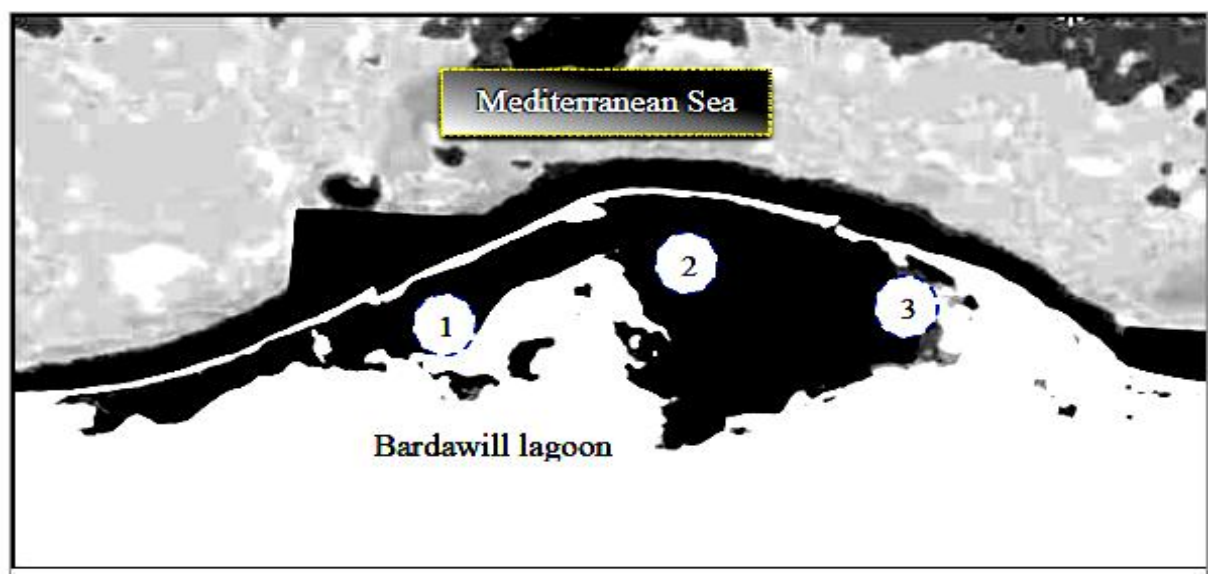

Figure 1. Map of Bardawill lagoon and study sites

The study began after the observation of illegal size landing of bream fishes in catch composition of trammel fishing units. Data were collected monthly from ten specified fishing vessels (Out board motors) it operated mostly in lagoon ( 3 from the west, 4 from the center and 3 from the eastern of lagoon). Vessels operated day and night (day with hooks and night with nets and longline) by four type of fishing gears; three vessels were operated by classic trammel net (demersal trammel) had $6.5 \mathrm{~cm}$ mesh sizes inner panel ( $\sim 33 \mathrm{~mm}$ mesh size square) with $2.5 \mathrm{~m}$ in depth (Outer panel with depth of $1.5 \mathrm{~m}$ ), four units were working interchangeably with modified trammel net (pelagic trammel) had $5.4 \mathrm{~cm}$ mesh size inner panel ( $\sim 27 \mathrm{~mm}$ mesh size square) with $2 \mathrm{~m}$ depth (Outer panel with depth of $1.5 \mathrm{~m}$ ) and gillnet had $3.6 \mathrm{~cm}$ mesh size upper inner panel $(\sim 18 \mathrm{~mm}$ mesh size square) and $6.5 \mathrm{~cm}$ mesh sizes lower inner panel ( $\sim 33$ $\mathrm{mm}$ mesh size square) with $2 \mathrm{~m}$ depth (Outer panel with depth of $2 \mathrm{~m}$ ) and the other three units were worked by lines (hand and longline) J-style hook No. 15 and 13 (Bend width equal 8 and $9.9 \mathrm{~mm}$ ). Gears measurement recorded on-site. The gears did not work at the same time and the same season. The data was collected within one day for each fishing group from the end of April to November 2017. In total, we assessed eight fishing trips of each unit group.

The total catches in general and bream in particular was recorded as a quantity each fishing day. Total quantity of bream landed were iced, labeled and transported to the laboratory in ice boxes. In the laboratory, Biometric data as total length $\left(L_{T}\right)$ to the nearest $0.1 \mathrm{~cm}$ and weighted to one gram were measured. Length - weight relationship of the fish was represented by the equation $\mathrm{W}=\mathrm{aL}^{\mathrm{b}}$, where ' $\mathrm{W}$ ' and ' $L$ ' are the weight and length; ' $a$ ' and ' $b$ ' are constants (Le Cren, 1951). With this equation, the total weight of adult landed fish was computed. The growth rates $(\mathrm{K})$ and asymptotic length $(\mathrm{L} \infty)$ were obtained using the FISAT II software (Sparre and Venema, 1992).

Length at first capture $\left(L c_{50}\right)$ value was determined using the probability of capture from the pooled length frequency distribution curve. The length was plotted taking $\mathrm{X}$-axis and the numbers caught in $\mathrm{Y}$-axis.
The instantaneous rate of natural mortality (M) was obtained by three methods: Ursin, 1967 (Mw $=W$ $\left.{ }^{0.333}\right)$, Jensen, $1996(\mathrm{M}=1.5 \mathrm{~K})$ and Hewitt and Hoenig, 2005( $\left(\mathrm{M}=\left(4.22 / \mathrm{T}_{\max }\right)\right)$. $\mathrm{T}_{\max }$ was estimated using the formula of Pauly and Munro, 1984: $\left(\mathrm{T}_{\max }=\right.$ $3 / \mathrm{K})$.

To determine the proportion of juveniles exploited, a total of 415 individuals were examined to determine the length at first maturity $\left(L m_{50}\right) . L m_{50}$ was determined by examination of gonads by fitting the maturation curve between the percentages of maturities of fish corresponding to each length class interval. Then $\mathrm{Lm}$ was estimated as the point on the $\mathrm{X}$-axis corresponding to $50 \%$ point on the $\mathrm{Y}$-axis. Accordingly, fish was classified to two groups; target (adult $>L m_{50}$ ) and by-catch (Juvenile $\leq L m_{50}$ ) to asses bio-economic of bream landings. Fish below $L m_{50}$ was accounted as a by-catch (undersized individuals) where must be allowed to spawn at least once before they get caught to sustain their stock. Average length $\left(L_{\text {mean }}\right) \mathrm{cm}$ of juvenile was taken as cut-off factor for estimating bio-economic losses for each month.

The catch recorded from the observed ten vessels on the day of observation was raised to total number of vessels, and then raised to the number of fishing days in fishing season. The proportion of juveniles and adults from observed length frequency data was determined.

The Biological loss was estimated by considering the landings and loss in weights of juveniles if they were permitted to grow to $L m_{50}$. Economic loss due to the capture of juveniles was estimated by considering the price of adult and juvenile for that fishing season. Methods of Najmudeen and Sathiadhas, (2008) were used to estimate the bioeconomic losses as follows:

$$
\mathrm{QA}=((1000 / \omega) \mathrm{W} / 1000)(1-\mathrm{M})
$$

where

$Q A$ : adult fish quantity corresponding to 1 kilogram

of juvenile fish after a period of $t$ year.

$W$ : weight of the individual adult fish after a period of $t$ years $\omega$ : individual weight of juvenile in gram. $M$ : Natural mortality 


$$
E L=\left(\frac{\sum_{i=1}^{n} \frac{C l Q_{l}}{(1-\delta)^{*}}}{n}\right)-\left(\frac{\sum_{i=1}^{n} \operatorname{ciq} i}{n}\right)
$$

where

$E L$ : average economic loss for the quantity of Bream juveniles landed per unit per fishing trip.

$C i$ : average price of adult.

$c i$ : average price of juvenile.

$Q i$ : is the estimated virtual quantity of the adult fish corresponding to the quantity of juvenile landed (qi).

$n$ : represents the total number of boats,

$\delta$ : is the standard discount rate $(\%)$,

$t$ : age in year at minimum catching size .

Price of juveniles and adult was recorded by

fishers, fisher's agents and fish retailers at the landing sites. During the study, 42 and 90 Egyptian pound (LE) was estimated as an average price for each kilogram of juvenile and adult gilthead seabream, respectively.

\section{RESULTS}

Six main species were recorded as a composition of trammel nets catches, Swimming crab constituted the most dominant fish species by weight $(51.2 \%)$ followed by Mullets (22.3\%), Seabream (12.7\% of them $7.2 \%$ of the classic net), Sole (11.8\%), Sea bass $(1.2 \%)$ and Shrimp (0.8\%). Seabream represented by $30.4,2.4$ and $7.6 \%$ in hand, longline and gillnet, respectively. Catches in longline were dominated by European eel as accounted for $80.1 \%$.

Results indicated that, observed total length of 940 Gilthead bream, Sparus aurata ranged from 15.2 to $29.8 \mathrm{~cm}$ and the weight from 47 to $385 \mathrm{~g}$. Sizestructure of fish were grouped in Figure 2. Midlength of $17.5 \mathrm{~cm}$ showed the highest frequency distribution (0-age group) and the highest length recorded during the study period was $29.8 \mathrm{~cm}$.

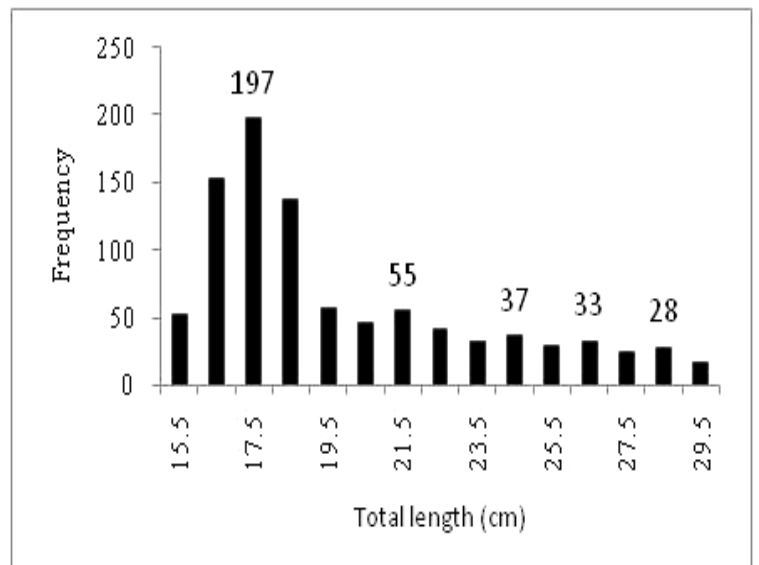

Figure 2. Size-structure of Gilthead Sea Bream, $S$. aurata.
The length-weight relationship (Figure 3) was described by the power equation as: $\mathrm{W}=0.019 * \mathrm{~L}^{2.911}$

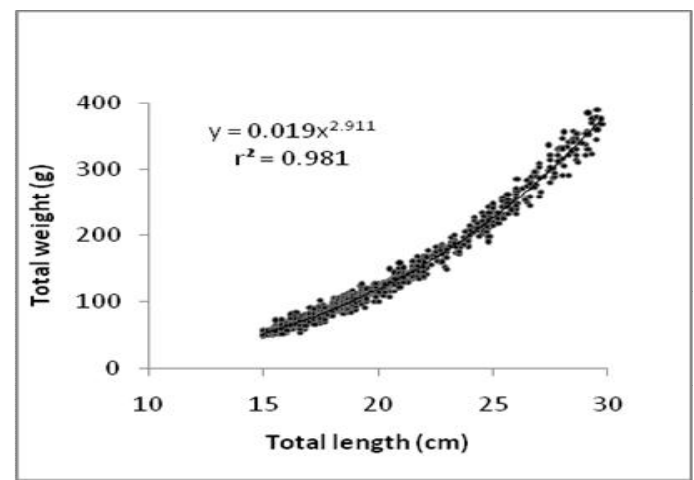

Figure 3. Length-weight relationship of bream, $S$. aurata

Employing computer based ELEFAN method the Growth parameters; $L \infty$ and $K$ were estimated at $31.63 \mathrm{~cm}$ and 0.53 per year, respectively (Figure 4 ).

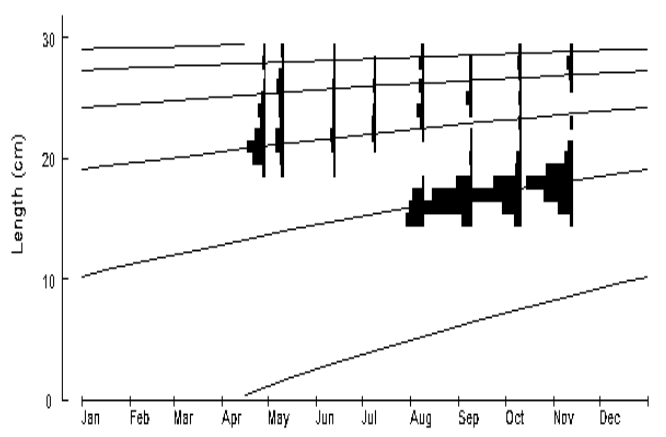
2017

Figure 4. Restructured length-frequency histogram of Bream, $S$. aurata $(\mathrm{L} \infty=31.63 \mathrm{~cm}, \mathrm{~K}$ $=0.53$ per year.)

The length at first maturity $\left(L m_{50}\right)$ equal $22.5 \mathrm{~cm}$ as shown in Figure 5. $\mathrm{Lm}_{50}$ corresponding to weight of $~ 164 \mathrm{~g}$. Juvenile landings was found to be $57.3 \%$ of total bream catch by weight.

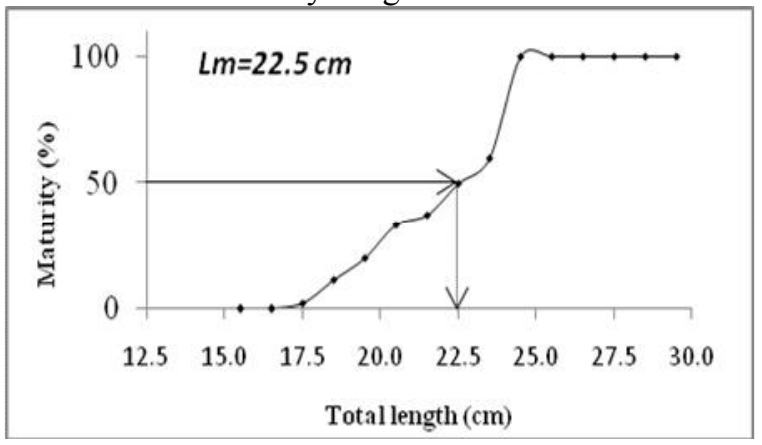

Figure 5. Length at first maturity $\left(L m_{50}\right)$ of bream, $S$. aurata 
The length at first capture $\left(L c_{50}\right)$ was estimated as $18 \mathrm{~cm}$ (Figure 6). $L c_{50}$ corresponding to weight of $85.7 \mathrm{~g}$.

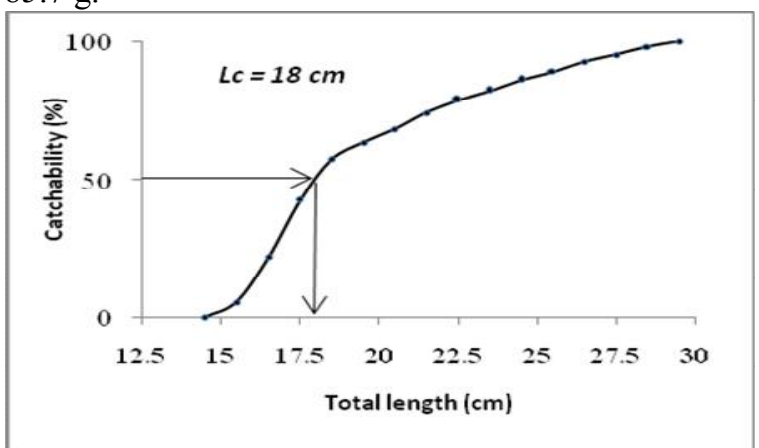

Figure 6. Length at first capture $\left(L c_{50}\right)$ of bream, S. aurata

Maximum biomass deficit (corresponding to one $\mathrm{kg}$ of juvenile) of the units was found in August. The second biomass deficit was recorded in September and October followed by November (Figure 7).

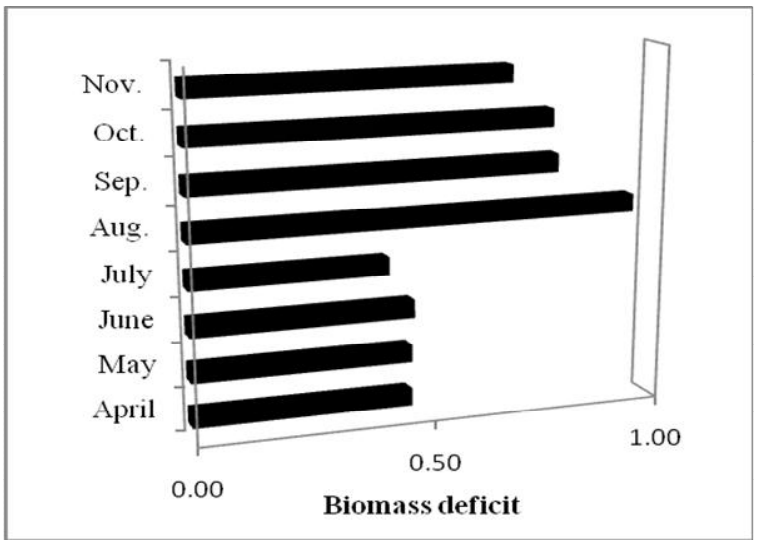

Figure 7. Monthly Biomass deficit corresponding to one $\mathrm{Kg}$ of juvenile Bream landing before reaching $L m \mathrm{~cm}$

Results indicated that, the mean length $\left(L_{\text {mean }}\right)$ of the juvenile individuals was $18.18 \mathrm{~cm}$ with an average weight of 88.2 g., the landing of juvenile leads to more losses of stock biomass. A biomass loss was found to be $\sim 295.2$ tonnes per year as shown in Table 1.

Table 1. Biomass loss of Gilthead bream, $S$. aurata in Bardawill lagoon, (2017)

$\begin{array}{lr}\text { Juvenile landing quantity (qi), } \mathrm{kg} / \text { unit / day } & 0.921 \\ \text { Adult quantity (QA) to1 kg of juvenile at } \operatorname{Lm}(\sim 1.5 \mathrm{yr}) & 0.781 \\ \text { Biomass quantity losses (Qi) kg / unit / day } & 1.640 \\ \text { Av. number of fishing units in Bardawill lagoon } & 1200 \\ \text { Activity fishing days / year } & 150\end{array}$

Biomass loss (tones)/fishing season

The present results showed that, annual biomass will be increased by $78.1 \%$ with 5.5 times the increase in revenue of fishing unit, if juveniles are caught up to $L m$ (Table 2).

Table 2. Economic loss of Bream, $S$. aurata in Bardawill lagoon, (2017)

\section{DISCUSSION}

Capture of Juvenile represents a waste of fishery because this would affect long-term conservation measures for fisheries (Clucas, 1997). This research is concerned with the estimation of biological and economic losses as a result of fishing of small gilthead Seabreams in Bardawill lagoon. Leaving small fish in the lagoon for one fishing season will give a future biological crop of a larger size, thus, higher income.

Results indicate that the bream resources in the lagoon were heavily fished in this period, relatively high $\mathrm{K}$ and low $\mathrm{L} \infty$ value indicated the short-lived of this species and that the continuation of current fishing regimes is not possible. These results were confirmed by Salem and El-Aiatt, (2013) who mentioned that, the current trammel gear units' practices resulted in higher exploitation of bream's juveniles in Bardawill lagoon and juvenile of bream was dominated in catches.

Most of bream landings $(57.3 \%$ of total bream weight) were immature fish; ( $L c_{50}$ equal $18 \mathrm{~cm}$ ) was considerably smaller than the length at first sexual maturity $\left(L m_{50}\right.$ equal $\left.22.5 \mathrm{~cm}\right)$. This means that stock of this species is deteriorating. If the length at first capture is correctly determined, the yield from the stock is optimized (Armstrong et al., 1990). 
From the present results, August recorded the highest biomass deficit during the fishing season. The high biomass deficit may be due to enter a new cohort to the fishing area. Also, The higher catches of juvenile caused by the higher depth $(2 \mathrm{~m})$ and the least mesh size (27 mm sq) of modified trammel net, where it captures the demersal species such as bream where that gear operated in shallow areas and soak for a long period. This result is confirmed by that of Cilbiz et al., (2014), where they reported that, lowering the legal mesh size up to $50-60 \mathrm{~mm}$ of gill net likely causes some negative results on the species in the environment. Pelagic trammel net is a dangerous gear when soaked a more time in water. Shabir et al., (2015) recorded huge economic loss by fishing of juveniles of 18 commercially important species by gillnetter had mesh sizes from 14 and 150 $\mathrm{mm}$ in Indian water. Juveniles of important species is problem in many fine mesh gillnet fisheries (Purbayanto et al., 2001). In study of juvenile fishing of sciaenids, Kamei et al., (2013) concluded that in trawlers operation cod end mesh size is increased at least marginally to $35 \mathrm{~mm}$. Modified trammel net (27 $\mathrm{mm} \mathrm{sq)} \mathrm{must} \mathrm{be} \mathrm{not} \mathrm{soaked} \mathrm{more} \mathrm{time} \mathrm{in} \mathrm{water} \mathrm{as}$ more soaking time can however have severe consequences for the demersal fishes. Clay', (1981) recorded that, duration set of nets, is one of the major factors that affect the fishing behavior. Hooks (No. 15 and 13) caught more breams undersize. these result confirmed by Erzini et al., (1998) and Salem, (2018), where they found that, smaller hooks (No. 15 and 13) caught more breams than larger hooks (No. 12 and 11).

In this study, the fishing units in the lagoon may lead to a loss of large amount of bream stock in the form of juvenile. The biological losses were estimated at least 295.2 tonnes annually. These fishes will reach marketable size at the next fishing season. In total catch, if these juveniles were not caught and allowed to grow up to $L m$, will add 295.2 tonnes biomass with revenue of 25.2 million LE. Mehanna et al., (2011) reported that the lagoon loses more than 3 million seabream juveniles and 2 million soles juveniles yearly which gave at least 30 million LE if they lived. Salem et al., (2017) estimated economic loss due to landing of fish as by-catch in gill net in Bardawill lagoon by 23.6 million LE.

In general, juvenile of bream fish from the nets we examined were relatively small (mean of 10 to 12 individual per $\mathrm{kg}$ ). In order to protect fish stock and to enable it to share at least for one time in reproduction, Juvenile exploitation and economic loss due to this must be controlled by fisheries managements as an urgent increasing in mesh size of fishing nets and hooks as well as the evaluation of all fishing techniques in the lagoon and prohibiting the dangerous ones must be done. Also, attention should be by awareness programs among fishermen and to make them understand the threats of exploitation of juveniles.

\section{REFERENCES}

Armstrong D.W., R.S.T. Ferro, D.N. MacLennan, S.A. Reeves, 1990. Gear selectivity and the conservation of fish. Journal of Fish Biology, 37 : 261-262.

Cilbiz, M., H Zübeyde, C. Nihal, Ç. Şakir, S. Soner, 2014. Multifilament Gillnet and Trammel Net Selectivity for the Silver Crucian Carp (Carassius gibelio Bloch, 1782) in Eğirdir Lake, Isparta, Turkey. Turkish Journal of Fisheries and Aquatic Sciences 14: 905-913.

Clucas I., 1997. A study of the options for utilization of by-catch and discards from marine capture fisheries. FAO Fisheries Circular No., 928.

Clay' D., 1981. A New Technique for Estimation of Gillnet Selectivity and Re-analysis of Data for Several Fish Species. NAFO Sci. Coun. Studies, NO.1: 7-22.

Diamond, S., L. Crowder and L. Cowell, 1999. Catch \& Bycatch: The qualitative effects of fisheries on population vital rates of Atlantic croaker. Trans. Am. fish. Soc., 128:1085-1105.

EEAA (Egyptian Environmental Affairs Agency), 2008. Egypt State of Environment Report. 356 pp.

Erzini, K., J.M.S. Goncalves, L. Bentes, P.G. Lino and J. Ribeiro, 1998. Species and size selectivity in a 'red' sea bream longline 'metier' in the Algarve (Southern Portugal). Aquatic Living Resources, 11: 1-11.

Greenstreet S.P.R, S.J. Hall, 1996. Fishing and ground-fish assemblage structure in the northwestern North Sea: An analysis of long-term and spatial trends. Journal of Animal Ecology.65 (5):577-598.

Hewitt, D.A. and J.M. Hoenig, 2005. Comparison of two approaches for estimating natural mortality based on longevity. Fishery Bulletin 103:433-437.

Jensen, A. L., 1996. Beverton and Holt life history invariants result from optimal trade-off of reproduction and survival. Can. J. Fish. Aquat. Sci. 53:820-822.

Kamei G., S. K. Chakraborty, G. Deshmukhe, A. K. Jaiswar, Hanjbam Mandakini Devi, Suman Kumari and G. B. Sreekanth, 2013. Assessment of economic impact of juvenile fishing of sciaenids along Mumbai Coast, India. Indian Journal of Geo-Marine Sciences, Vol. 42(5): 617621.

Le Cren, E.D., 1951. The length-weight relationship and seasonal cycle in gonad weight and condition in the perch (Perca fluviatilis). J. Anim. Ecol., 20(2): 201-219. 
Mehanna S.F., A. Aiatt and M. Salem, 2011. An investigation of the impacts of shrimp bottom trawling on the Bardawill lagoon fisheries. Egypt. Egypt. J. Aquat. Biol. \& Fish., 15 (3): 415-424.

Najmudeen, T.M. and R. Sathiadhas, 2008. Economic impact of juvenile fishing in a tropical multi-gear fishery. Fish Res., 92322-92332.

Pauly, D., J.L. Munro, 1984. Once more on the comparison of growth in fish and invertebrates. ICLARM Fishbyte 2 (1), 21.

Purbayanto, A., A. Tsunoda, S. Akiyama, T. Arimoto, T. Tokai, 2001. Survival of Japanese whiting and by-catch species captured by sweeping trammel-net. Fish.Sci. 67: 21-29.

Salem M., 2011. Population dynamics and fisheries management of Gilthead sea bream, Sparus aurata (f. Sparidae) from Bardawill lagoon, North Sinai, Egypt. Egypt. Egypt. J. Aquat. Biol. \& Fish., 15 (1): 57-69.

Salem M., 2018. Preliminary Assessment and Mitigating By-Catch of European Eel in a Longline Fishery in Bardawill Lagoon, North Sinai, Egypt. Egyptian J. Anim. Prod. (2018) 55(3):187-194.
Salem M. and A. El-Aiatt, 2013. Improvement of trammel net landing and reduction of fishing for gilthead seabream, Sparus aurata juveniles in Bardawil lagoon, North Sinai, Egypt. Journal of Animal, poultry \& Fish Production, Suez Canal University, 1: 36-41.

Salem M., R. Ismail, A. El-aiatt, M. Gaber, and R. Eid, 2017. Biological and economical Evaluation of by catch and discards of fisheries for gill net in Bardawill lagoon. J. Egypt. Acad. Soci. Environ. Develop. (In Press).

Shabir, A. D., N. T. Saly, S. K. Chakraborty, G. B. Sreekanth and M. H. Balkhi, 2015. Economic loss assessment on juvenile fish catch due to forced non-selectivity in a selective fishing gear, gillnet along Mumbai coast, India. Journal of Applied and Natural Science 7 (2) : 916 - 921.

Sparre P, S.C. Venema, 1992. Introduction to tropical fish stock assessment. Part I. Manual. FAO Fish Tech pp: 376.

Ursin, E., 1967. A mathematical model of some aspects of fish growth, respiration, and mortality. J. Fish. Res. Board of Canada 24: 2355-2453.

\section{تقييم الفقد البيوإقتصادى لإنتاج اسماك الدنيس ، Sparus aurata في مصيد منخف البردويل، ساحل المتوسط، شمال سيناء، مصر اليور

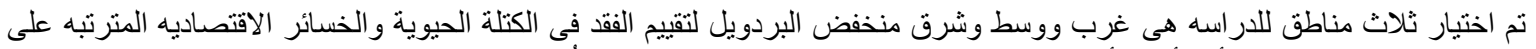

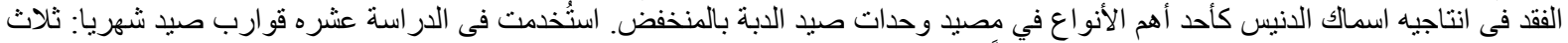

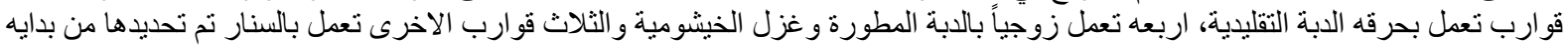

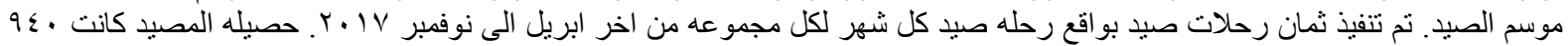

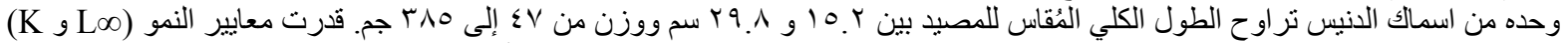

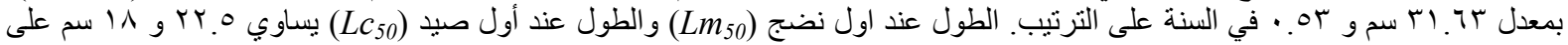

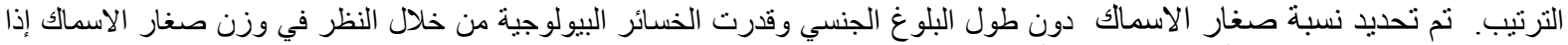

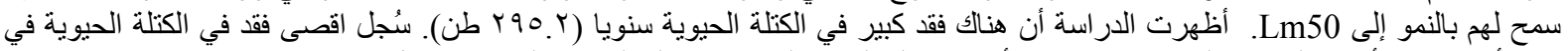

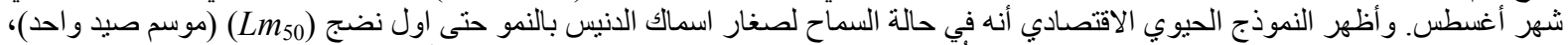

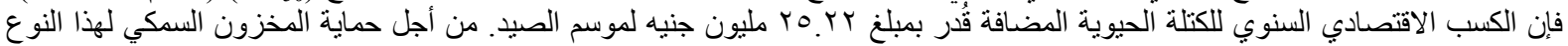

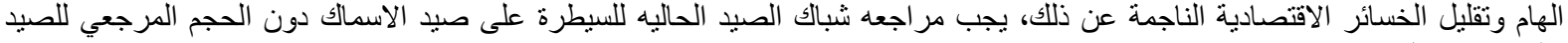

